\title{
Turismo e desenvolvimento: reflexões acerca de uma complexa relação ${ }^{1}$
}

\section{Tourism and development: reflections about a complex relationship}

\section{Guilherme Augusto Pereira Malta, Maria Flávia Pires Barbosa}

\begin{abstract}
RESUMO
Pode-se dizer que o turismo, do ponto de vista do desenvolvimento, é frequentemente apontado como um meio capaz de induzi-lo em uma dada realidade e/ou como parte de uma estratégia para se alcançá-lo. A relação entre esses termos, amplamente abordada nos estudos que trabalham a noção de turismo local e comunitário, é tema principal deste trabalho. Como esforço inicial de compreensão, foram identificadas o que aqui se denominou de abordagens de desenvolvimento, a partir, sobretudo, da literatura dedicada ao estudo do turismo. Destacou-se que essas abordagens, ou seja, as distintas formas de se enxergar o turismo dentro dos processos de desenvolvimento, encontram-se em disputa no campo dos estudos turísticos e no âmbito de sua promoção, por representarem, a princípio, diferentes possibilidades de leitura e compreensão do desenvolvimento e de sua relação com a atividade turística. Por meio dessa análise, tornou-se possível avançar na crítica aos enfoques identificados, assim como refletir sobre até que ponto a identificação de diferentes abordagens de desenvolvimento representa, na prática, novos caminhos para a promoção do turismo. De maneira complementar a essa discussão foi trabalhada, também, a relação existente entre as abordagens de desenvolvimento aqui identificadas e as principais perspectivas de planejamento turístico. Espera-se, dessa maneira, contribuir para o debate em torno do turismo local-comunitário e das questões que o tema busca suscitar.
\end{abstract}

PALAVRAS-CHAVE: Desenvolvimento; Planejamento; Turismo Local-Comunitário.

\section{ABSTRACT}

Tourism is frequently seen as a means capable of inducing development within a certain context and / or as part of a strategy to achieve it. The relationship between development and tourism, widely discussed in papers dealing with the notion of local tourism and community, is the main theme of this work. As an initial effort of understanding, we have identified what's been called development approaches, that is, the main ways of viewing tourism within development processes. It was emphasized that such approaches are in dispute both in tourism studies and in their implementation, as they represent different possibilities to understand development and its relationship with tourism activity. Through this analysis, it was possible to go deeper into the evaluation of the identified approaches, as well as to reflect on how far the identification of different development approaches represents, in practice, new ways of promoting tourism. Furthermore, the relationship between development approaches and the identification of the main perspectives of touristic planning will also be discussed. We expect, in this way, to contribute for the discussion on local community-based tourism and for the issues raised by this topic.

KEYWORDS: Development; Tourism Planning; Local Community-Based Tourism.

Página 862 Revista Brasileira de Ecoturismo, São Paulo, v.6, n.5, nov 2013-jan 2014, pp.862-895. 


\section{Introdução}

A referência à relação estabelecida entre o turismo e o desenvolvimento é comum em grande parte das obras que têm a atividade turística como objeto de estudo. Desde os grandes manuais de introdução ao turismo aos artigos que se propõem a analisar sua exploração em uma dada área geográfica, há uma concordância geral de que a promoção da atividade turística contribui, em algum grau, para a instauração de um processo de desenvolvimento. Ao se tratar a atividade turística sob uma perspectiva econômica, reconhecida pela expressiva capacidade de geração de emprego e renda, tornou-se quase natural associar o turismo ao desenvolvimento, seja como uma estratégia, seja como um instrumento capaz de induzi-lo em uma dada realidade. Entretanto, na literatura, raramente se percebem o questionamento e a análise crítica direcionada à real compreensão da relação estabelecida entre esses termos.

O objetivo principal deste trabalho consiste, então, em compreender pontos fundamentais oriundos do elo estabelecido entre o turismo e o processo de desenvolvimento ${ }^{2}$. Assim, questiona-se a forma como as obras e estudos da área trabalham e compreendem o turismo dentro da dinâmica de desenvolvimento, buscando verificar qual o lugar ocupado pela atividade turística neste processo. Desta maneira, indaga-se quais são as abordagens e os enfoques de desenvolvimento discutidos pelos autores, visando, paralelamente, discutir de forma crítica a relação estabelecida entre tais abordagens e as principais perspectivas de planejamento turístico existentes.

Nesse sentido, é igualmente importante perceber o amplo campo que o termo desenvolvimento abrange enquanto conceito de grande influência sobre o pensamento e o comportamento humanos. Ao mesmo tempo, a enorme variedade de conotações absorvidas pela palavra desenvolvimento, sobretudo ao longo do século XIX, acabou por desgastar uma suposta precisão de seu significado, alcançando, dessa maneira, o status de simples expressão, cuja tradução depende, na maioria das vezes, do contexto em que é utilizada (ESTEVA, 2000). A mesma crítica, inclusive, pode ser estendida ao uso desse termo quando associado ao turismo, uma vez que se constatou ser recorrente seu emprego indiscriminado e pouco reflexivo pela literatura da área.

Convém destacar que o turismo, além de atividade econômica, também se caracteriza como prática social, cultural e espacial. Como tal, é capaz de dinamizar e/ ou articular diversas atividades e ramos da economia, sem, contudo, deixar de refletir também as determinações da sociedade na qual está inserida: contraditória, conflituosa, controversa, desigual, reflexo de lógicas do momento histórico presente, da globalização e/ou da nova fase do capitalismo, dita ecológica ou sustentável (O'CONNOR, 1988). Dessa forma, o modelo de desenvolvimento ainda baseado na produção em massa e no consumo exacerbado associado à lógica de crescimento ilimitado, inerentes à estrutura e à dinâmica do capitalismo, se estende também à 
lógica predominante no turismo, independentemente, muitas vezes, de qual seja sua denominação ou tipologia.

Diante das conhecidas características negativas da economia capitalista - que também se encontram reproduzidas na dinâmica econômica e social do turismo evidencia-se a necessidade do questionamento constante da noção de desenvolvimento, tão intrínseca ao projeto capitalista e tradicionalmente centrada na aceleração do crescimento econômico. Essa concepção, segundo Santos (2005), acaba por implicar "na marginalização de outros objetivos sociais, econômicos e políticos, como a participação democrática na tomada de decisões, a distribuição equitativa dos frutos do desenvolvimento e a preservação do meio ambiente" (SANTOS, 2005, p.45). Cabe questionar, assim, quais são as formas de se conceber e retratar o desenvolvimento, a partir do ponto de vista de alguns autores da área e que se fazem presentes nesta análise.

Em virtude das indagações aqui propostas, espera-se, com o presente trabalho, provocar novos questionamentos e reflexões acerca do turismo e de seu estreito elo com o desenvolvimento, bem como acerca de sua relação com algumas perspectivas de planejamento, buscando esclarecer, portanto, o que a relação entre turismo e desenvolvimento pretende comunicar, dissimular e convencer.

A identificação de abordagens ou enfoques do desenvolvimento implícitas no turismo, bem como as críticas direcionadas ao uso do conceito de desenvolvimento pelas obras da área surgem como uma tentativa de propiciar uma leitura mais clara e, ao mesmo tempo, mais crítica em torno deste tema. A contribuição para a consolidação de uma base mais sólida acerca do conhecimento turístico e sua interface com o desenvolvimento surge, então, como uma das principais razões que motivaram a construção deste artigo.

Sendo assim, esse artigo se inicia com a construção de uma base crítica acerca dos fundamentos do turismo, que visou possibilitar a compreensão dos seus principais traços e características. Nesse sentido, optou-se por obras de caráter mais abrangente acerca de sua dinâmica de promoção, a fim de situar o objeto de análise $\mathrm{e}$, assim, trabalhar os pontos considerados fundamentais pela literatura da área. Cabe ressaltar que, dentro dos estudos de turismo, abordaram-se pontos que, direta ou indiretamente, contribuíssem para o entendimento do tema deste trabalho.

Assim, buscou-se apontar aspectos essenciais que contribuíssem para o segundo momento, no qual se buscou identificar e analisar, de forma específica, as abordagens do desenvolvimento apresentadas pelas obras de turismo que foram aqui utilizadas. Anteriormente a discussão das abordagens tornou-se necessário, contudo, resgatar algumas visões sobre o desenvolvimento, a partir, sobretudo, da trajetória da construção social do significado histórico-político do termo. Com isso, objetivou-se trazer novos elementos para a discussão, no intuito de ampliar as perspectivas de compreensão em torno do conceito de desenvolvimento.

Paralelamente, foram discutidas, também, a relação estabelecida entre tais

Página 864 Revista Brasileira de Ecoturismo, São Paulo, v.6, n.5, nov 20।3-jan 20I4, pp.862-895. 
abordagens e as principais perspectivas de planejamento turístico existentes.

\section{Considerações sobre o Turismo}

O debate acerca do que vem a ser o turismo, apesar de recorrente já há algumas décadas no meio acadêmico, ainda guarda inúmeras divergências no que se refere aos conceitos construídos para definir esta atividade. Segundo Ignarra (1999), o turismo, desde 1910, é objeto de discussão e elaboração conceitual.

O turismo, em virtude de sua complexidade e abrangência, que o faz transitar por diversas áreas do conhecimento, possui inúmeros enfoques de análise ${ }^{3}$. Destacase, neste contexto, como lembra Magalhães (2008), que "nenhuma outra área do conhecimento vem ganhando tanto destaque quanto o turismo, seja pela sua dimensão econômica, seja pela problemática social que ele enseja" (MAGALHÃES, 2008, p.96).

Para o presente trabalho, optou-se por adotar abordagens que, de forma direta, contribuem para a compreensão da relação estabelecida entre turismo e o desenvolvimento, ou melhor, as diferentes maneiras de apropriar da ideia ${ }^{4}$ de desenvolvimento. Por outro lado, há de se reconhecer, de acordo com Souza (1997) que "a literatura científica sobre o desenvolvimento não tem dedicado ao turismo uma atenção à altura da importância que ele, cada vez mais, possui” (SOUZA, 1997, p.17).

Ressalta-se que, a partir de uma revisão crítica sobre o turismo, serão apresentadas nesse artigo as diferentes formas de compreensão que existem em torno deste tema. Este exercício inicial possui por intenção conceituar o turismo e buscar entender suas principais características e abordagens a partir da seleção de artigos e obras que tratam deste tema.

Inicialmente, uma das maiores dificuldades em definir o turismo de forma significativa e que seja amplamente aceita está diretamente relacionada aos seus aspectos multidimensionais e suas interações com outras atividades (GOELDNER; RITCHIE; MCINTOSH, 2002). Conforme afirmam Margarita Barreto e Rafael Santos (2005, p.358), um dos principais problemas que envolvem os chamados Estudos Turísticos reside no fato do "turismo constituir-se, simultaneamente, em objeto de estudo científico e em área de ação do marketing e de outros fazeres que privilegiam sua dimensão de negócio". O caráter híbrido do turismo reflete, por sua vez, a completa ausência de consenso quanto à sua conceituação. Por mais que haja definições pré-estabelecidas e amplamente divulgadas sobre o turismo, como a definição defendida pela Organização Mundial de Turismo (OMT), a literatura da área deixa claro a inexistência de um conceito unívoco que represente esta atividade. A própria OMT, apesar da tentativa de padronização do conceito de turismo, deixa claro que o mesmo é marcado pela ausência de definições conceituais claras que delimitem a atividade e a distinga de outros setores econômicos (OMT, 2001).

Além da diversidade de definições que existem acerca do turismo, destaca-se a 
multiplicidade de áreas que se interpenetram em seu estudo ${ }^{5}$. Em virtude disso, são atribuídos ao turismo, simultaneamente, os caráteres de objeto de estudo científico e atividade econômica, fato que se constitui, portanto, em uma das principais peculiaridades deste campo. Autores como Magalhães (2008), por exemplo, interpretam essa dualidade como algo perigoso, já que abre espaço para a redução do turismo a uma perspectiva puramente comercial, impedindo-o de atuar como meio de entendimento do real ou como ciência.

É preciso ressaltar, de acordo com Goeldner et al. (2002), que "cada uma das muitas definições que surgem destina-se a uma situação específica ou a resolver um problema imediato" (Goeldner et al., 2002, p.24). Lickorish e Jenkins (2000) reiteram esta máxima e afirmam que a maioria dos escritores acadêmicos que abordam 0 turismo tende a adaptar suas definições para melhor atender seus objetivos. Dessa maneira, a falta de definições uniformes advindas deste contexto dificulta o estudo do turismo como disciplina (GOELDNER et al.,2002).

Entretanto, ao se fazer referência ao turismo como uma disciplina, ou seja, que possui caráter de ciência, remete-se ao debate que questiona exatamente o caráter científico associado a esta atividade. Lohmann e Netto (2008) apresentam três principais correntes que se encontram em disputa no campo dos estudos turísticos ou, como denominam os autores, no campo da epistemologia. É importante lembrar que as proposições contidas em cada uma dessas linhas podem ser associadas à grande parte da bibliografia do turismo e não devem ser entendidas enquanto posicionamentos estanques. Ao mesmo tempo, a divisão da discussão sobre o caráter científico do turismo em três correntes principais não busca encerrar este debate, mas tem por finalidade apresentar e organizar a visão geral dos autores que escrevem a respeito deste tema.

A primeira corrente, mais próxima do que se pode considerar como consensual sobre o turismo, acredita que apesar de não ser uma ciência, ele está trilhando o caminho para tornar-se uma, pois passa atualmente pelas mesmas fases de outras ciências que surgiram no inicio do século XX, tais como a Antropologia e a Etnografia. Autores como Ignarra (1999) defendem que, apesar do turismo ainda não poder ser considerado uma ciência, já que seu estudo de forma científica se iniciou há poucas décadas e, pela sua magnitude, como fenômeno, ainda carecer de aprofundamento técnico-científico, isso não exclui a possibilidade do turismo, em longo prazo, vir a se tornar uma ciência.

A segunda envolve uma significativa parte da literatura do turismo, sobretudo de autores oriundos de outras áreas do conhecimento, e afirma que o turismo não é e nunca será uma ciência, pois se constitui somente como uma atividade humana, sendo apenas auxiliado pelas ciências em seus estudos. Visões mais críticas e incisivas sobre o turismo, baseadas no significado formal de ciência, reiteram a incompatibilidade entre a atividade turística e a ciência. Segundo Barreto e Santos (2005),

Página 866 Revista Brasileira de Ecoturismo, São Paulo, v.6, n.5, nov 20I3-jan 20I4, pp.862-895. 
se partirmos da ideia de que a ciência é uma forma de explicar, compreender ou interpretar a realidade e de que o turismo é uma atividade ou uma prática que implica movimento de pessoas em situações definidas com utilização de determinados equipamentos e serviços, está claro que turismo não é ciência, nem fazer turismo ou trabalhar na área de turismo é fazer ciência (BARRETO; SANTOS, 2005, p.360).

Por último, uma terceira corrente defende que o turismo é uma ciência por possuir um corpo teórico maduro e relativamente grande, mas segundo Lohmann e Netto (2008), esta visão ainda não foi comprovada, por meio de estudos, pelos pesquisadores que se posicionam favoráveis à mesma ${ }^{6}$.

Deve-se ressaltar que, por mais amplas que possam parecer, estas três correntes não são as únicas formas de se interpretar o turismo e suas abordagens de estudo. Magalhães (2008) traz em sua análise, por exemplo, apenas duas perspectivas/caminhos para se abordar o estudo do turismo: a primeira delas se relaciona ao turismo como uma técnica e como mero instrumento para a profissionalização, sem referências históricas e voltada exclusivamente para atender as necessidades do mercado; e a segunda vê o turismo como uma ciência, compreendido a partir de sua totalidade histórica e com sua dimensão explicativa partindo da economia, da política, da cultura e dos aspectos sociais que cercam uma comunidade (Ibidem, p.96).

É necessário apontar, segundo Magalhães (2008) que o turismo apresentado nesta última perspectiva, somente poderá ser entendido enquanto ciência na medida em que os responsáveis pela construção de seu conhecimento priorizem conteúdos mais politizados e históricos. Há que se perceber que o autor, aponta de forma simplificada e determinista, a partir da multidisciplinaridade presente no estudo do turismo, um caminho que o levará a ser considerado uma ciência. Portanto, o sentido atribuído a perspectiva que compreende o turismo como uma ciência adquire, nessa abordagem, um significado específico e particular se comparado ao significado formal de ciência, que se refere, de forma geral, ao conjunto de conhecimentos concernentes a certas categorias de fatos ou fenômenos.

Dessa maneira, permeiam a literatura da área diversas visões e posicionamentos sobre qual seria o conceito mais adequado de turismo, além de questionamentos acerca de sua validade científica. Não se espera, no entanto, trazer todas as definições sobre o turismo nem tão pouco trabalhar com todas as correntes até então apresentadas.

A respeito da análise do turismo e de suas diversas abordagens, Jafari (2005), por sua vez, contribui para o tema por meio da identificação das cinco fases de estudo pelo qual o turismo passou desde a década de $1950^{7}$. As cinco fases ou, como define o autor, plataformas do pensamento em turismo, atuam como um resumo dos posicionamentos sobre a atividade turística, envolvendo tanto o meio acadêmico como os órgãos públicos responsáveis. Dispostos ao longo dessas cinco plataformas, o autor apresenta os principais posicionamentos que a sociedade e o meio cientifico e 
acadêmico tiveram em relação ao turismo e como isso refletiu em seu estudo, nestas últimas seis décadas.

A plataforma de defesa (advocacy platform) é a primeira apresentada por Jafari (1994) e se refere a uma visão romantizada da atividade. Neste primeiro momento, que compreende o período pós Segunda Guerra, acreditava-se que a promoção do turismo traria divisas do exterior, criaria empregos, e seria, acima de tudo, bom para a economia $^{8}$. No Brasil, sobretudo na década de 1960, o turismo era compreendido como um instrumento capaz de reconstruir a economia (SANTOS et al., 2009). Esta plataforma representa um momento inicial, em que foram destacados apenas os pontos positivos do turismo. Os benefícios do turismo foram então amplamente divulgados em artigos de jornais, livros e documentos da Organização Mundial do Turismo (OMT), entre outras associações (LOHMANN; NETTO, 2008).

Na sequência e em oposição à primeira plataforma, a plataforma de advertência (cautionary platform) destaca os pontos negativos e malignos do turismo. O turismo era identificado, especialmente no período que compreendia o início da década de 1980, como destruidor da cultura local e dos recursos naturais, apontado como uma atividade essencialmente voltada para os turistas, ignorando as necessidades da comunidade local e, consequentemente, gerando conflitos. Os estudos mais críticos relacionados ao turismo baseiam-se, predominantemente, em suas características negativas e o apontam como responsável por alavancar um processo de desenvolvimento ambientalmente predatório e socialmente segregador (CANDIOTTO, 2007).

A terceira, denominada plataforma da adaptação (adaptancy platform), se refere ao momento em que, segundo Lohmann e Netto (2008, p. 45), uma vez contadas as boas e as más histórias sobre o turismo, seria necessário decidir quais as formas menos impactantes da atividade. Ganha força, a partir deste contexto, opções como turismo de aventura, agroturismo, turismo cultural, ecoturismo e turismo junto à natureza, entre outras ${ }^{9}$. Em uma clara referência a esta plataforma, Gomes et al. (2006) salientam que, a partir dos anos de 1970, "os estudiosos passaram a estudar uma forma de viabilizar um turismo que provocasse menos impacto" (GOMES et at., 2006, p.41). Lembrando que somente na década de 1990 estas ideias chegaram ao ambiente empresarial.

A quarta plataforma (knowledge-based platform) baseia-se no conhecimento concentrado ao redor do turismo. Segundo Jafari (1994), esta plataforma representa o momento em que foi criado um corpo de conhecimentos turísticos, o que possibilitou que muitas universidades voltassem sua atenção para esta temática. Por outro lado, como referido inicialmente, não há unanimidade quanto à natureza do conhecimento produzido pelos estudiosos de turismo. Autores como Barreto e Santos (2005), denominam o conhecimento turístico como um tipo de conhecimento mercadológico, que se volta para a organização da produção, circulação e consumo de bens e serviços, obedecendo, portanto, aos imperativos do mercado. Tal conhecimento 
mercadológico, como escrevem estes autores, estaria, atualmente, assim como os saberes populares, reivindicando algum tipo de hegemonia ao lado dos domínios da ciência ortodoxa. A presença e recorrência do conhecimento mercadológico no campo dos estudos turísticos é tão marcante que chega a ser frequentemente confundido com o conhecimento científico. (BARRETO; SANTOS, 2005).

A última plataforma, acrescentada recentemente pelo autor, se denomina plataforma pública (public platform). Segundo Lohmann e Netto (2008), no momento atual, a discussão acerca do turismo alcançou o público não especializado, em virtude dos episódios da pneumonia asiática (Sars) e dos atentados terroristas de 11 de setembro de 2001, nos Estados Unidos, e de 11 de março de 2004, ocorrido em Madrid, na Espanha. A evolução das plataformas, como observam Santos et al. (2009), contribui para a reformulação constante dos conceitos de turismo, e de acordo com a abordagem utilizada - defesa, advertência, adaptação, conhecimento e pública - serão adotadas diferentes definições de turismo. Apesar de relacionadas e balizadas pelo fator tempo e de serem reflexo do crescimento do turismo ao longo do período analisado, as plataformas não devem ser entendidas como estritamente associadas a uma época. É importante levar isto em consideração, já que muitas destas posições ainda são defendidas, propagadas e coexistem nos dias atuais.

Em uma linha de análise semelhante, Goeldner et al. (2002) complementam a noção apresentada por Jafari, por meio da sistematização das principais abordagens do estudo do turismo. Os autores deixam claro, novamente, que apesar do turismo ser analisado por meio de uma série de métodos, existe "pouco ou nenhum consenso sobre como o estudo deste campo deverá ser desenvolvido" (GOELDNER et al. 2002, p.28). A partir da identificação de oito principais abordagens ${ }^{10}$, são apresentadas, assim como nas plataformas defendidas por Jafari (1994), inúmeras formas de se compreender o turismo. As abordagens oscilam entre a esfera econômica do turismo, passando por seu caráter de atividade social e até mesmo geográfica. Muitas dessas abordagens, por estarem focadas nos benefícios econômicos do turismo, em especial no chamado desenvolvimento turístico, aproximam-se da plataforma de defesa, como sugerido por Jafari. Por outro lado, abordagens mais críticas e amplas como a geográfica e as interdisciplinares buscam envolver aspectos mais abrangentes sobre o turismo, ultrapassando seu caráter econômico e seus atributos unicamente positivos.

Visto que o turismo possui diversos enfoques e/ou ângulos pelos quais pode ser compreendido, fica clara a dificuldade inicial ao se adentrar no campo dos estudos turísticos. O turismo pode ser caracterizado, assim, enquanto conceito, como matéria bastante controversa segundo os vários autores que tratam desse assunto (IGNARRA, 1999). Diante das características do turismo, então, e mesmo diante de todas as dificuldades metodológicas, é inevitável continuar a questionar sobre qual a sua natureza - seria simplesmente uma atividade econômica ou um campo de estudo que caminha para se tornar uma ciência?

Mediante todas estas características e inquietações, agora espera-se discutir, a seguir, quais são os conceitos, ao menos os mais usuais, utilizados na tentativa de se 
apreender o turismo. A predominância de abordagens que reduzem o olhar, por contemplarem os aspectos do turismo de forma isolada, apesar de uma constante, não deixa de ser alvo de críticas por parte da literatura da área. Nesse sentido, Magalhães (2008) alerta que:

\begin{abstract}
Muitos ainda insistem em pensar o turismo simplesmente como prática, ou como técnica deixando de percebê-lo como um fenômeno social amplo, complexo e contraditório, que afeta todo o mundo e todas as camadas sociais, mesmo aquelas que não participam de forma direta de sua prática (MAGALHÃES, 2008, p. 96).
\end{abstract}

Ao voltar o foco para a limitação representada nas análises que contemplam apenas alguns poucos aspectos do turismo, se espera, em contrapartida, chamar a atenção para o fato de que "o turismo é muito diverso quanto a suas formas de realização, suas motivações, seus impactos, os lugares onde pode acontecer etc." (OLIVEIRA, 2006, p.39). Dessa forma, qualquer tentativa de generalização da atividade deve, também, ser evitada e acaba sendo inválida. Ao tratar das diversas formas de conceituar o turismo e suas variadas leituras, busca-se tornar clara a dimensão deste objeto, para que, posteriormente, se possam questionar as abordagens de desenvolvimento implícitas nestas análises. Conforme ressalta Luchiari (1998): "Há tantas formas de turismo como possibilidades de análise desta atividade" (LUCHIARI, 1998, p.15).

\title{
Desenvolvimento e Turismo: uma relação complexa
}

Ainda que se concorde que a relação entre os temas abordados seja bastante complexa, é necessário, a priori, reconhecer que o desenvolvimento, enquanto processo histórico, possui traços essenciais e recorrentes na literatura que o aborda e que, portanto, devem ser destacados. A noção de desenvolvimento, bem como de toda a sua dinâmica de funcionamento, seja ela social, ambiental ou econômica, deve ser encarada, pois, como uma realidade historicamente constituída (SINGER, 1982).

Tomando como principal referência a compreensão do desenvolvimento a partir das obras e estudos que tratam do turismo, é possível perceber, logo de início, o forte caráter economicista direcionado à relação estabelecida entre esses temas. Nesse sentido, em diversos momentos, o foco da análise volta-se para a forma a partir da qual a promoção do turismo pode influenciar no estímulo ao crescimento econômico de uma determinada localidade ou região.

Autores como Sen (2000), que trabalham uma visão particular de desenvolvimento, a ser melhor explicitada adiante, apontam tal abordagem, pautada no crescimento econômico, como sendo uma das mais conservadoras de desenvolvimento, já que se baseia, por exemplo, no crescimento do Produto Nacional Bruto (PNB) ou no grau de industrialização. Souza (1997) adverte, por sua vez, que o desenvolvimento "não deve ser entendido, sublinhe-se, como sinônimo de 
desenvolvimento econômico, embora muitos, e não só os economistas, continuem a reduzir este a aquele" (SOUZA, 1997, p.18).

Visto que em diversos momentos é mencionada a relação entre desenvolvimento e crescimento econômico, cabe aqui, de forma objetiva, introduzir algumas considerações acerca deste tema. Vale destacar, inicialmente, a constante superposição no uso destes conceitos em diversas análises que buscaram discutir o desenvolvimento associado ao turismo, mesmo que estes, na prática, possam representar caminhos opostos e que se rivalizam.

Ainda que não haja unanimidade quanto à relação estabelecida entre ambos os termos, se sinônimos ou conceitos com diferentes significados, percebe-se que o desenvolvimento não consegue se desassociar das palavras que o acompanham desde sua origem: crescimento, evolução, maturação (ESTEVA, 2000). Entendido como um "construto ocidental", o desenvolvimento abarca e implica em ideias como crescimento, transformação e acumulação, que invariavelmente são utilizadas enquanto princípiosguia de uma série de políticas. A 'transformação' é apontada por Ribeiro (2008), inclusive, como "o núcleo duro do desenvolvimento como ideologia e utopia e que, muitas vezes, a transformação é almejada por povos locais de diferentes origens culturais" (RIBEIRO, 2008, p.120). É pertinente relembrar que o conceito de desenvolvimento informa invariavelmente uma ação, assim como um processo de melhora e ocorre em determinado território, mediante a ajuda da ação pública para promovê-lo (REIS, 2005). Deve-se considerar, no entanto, que em virtude da transformação sofrida por este conceito ao longo do tempo, deixou-se de considerar a ação que ele implica para, segundo Reis (2005, p.12), "considerarem uma sucessão impessoal de eventos, orientados sob uma certa direção e dotados de um sistema de autorregulação particular". Ou seja, na concepção deste último autor, passou-se a compreender o desenvolvimento como um processo passível de estruturação e ordenação. Ainda que não se possa negar a existência de algum tipo de ordem nos processos de desenvolvimento e transformação social, Reis (2005) ressalta a insistência em se descobrir "a lei fundamental", a "causa primeira", o "objetivo último", de uma dinâmica que é, por natureza, "imprevisível e não planificável".

No que se refere à estreita relação estabelecida entre desenvolvimento e crescimento, no caso específico do turismo, torna-se clara, em boa parte dos estudos e trabalhos nesta área, a constante confusão entre tais termos, que são utilizados indiscriminadamente para se referir aos benefícios que podem vir a ser gerados pela atividade turística. A esse respeito, Souza (1997) complementa que, ainda que dificilmente alguém possa sugerir que crescimento e modernização tecnológica sejam os principais objetivos dos esforços desenvolvimentistas, "a ideologia do desenvolvimento dominante, além de flagrantemente etnocêntrica ${ }^{11}$, costuma abrigar uma confusão entre meios e fins" (SOUZA, 1997, p.18).

Por outro lado, para além da ideia convencional de desenvolvimento, que ainda o associa estritamente a crescimento econômico, a análise do desenvolvimento vem incorporando outras questões como a influência da sociedade, a história, a cultura, a 
política, as especificidades locais, atores e instituições em seus diversos âmbitos. Faria (2006) observa que, com a agregação de novos elementos à discussão, o tema tem se tornado cada vez mais complexo e desafiador, implicando, dessa maneira, na indagação de suas recomendações para além de seu valor econômico. Porém, ainda que atualmente o tema do desenvolvimento esteja em um processo de discussão e questionamento, reafirma-se que o fortalecimento da base econômica continua a ser considerado, por parte significativa dos estudos voltados para este fim, como essencial para a melhoria da qualidade de vida das populações. Em sua concepção, sobretudo no pós Segunda Guerra, motivada por discursos políticos e progressistas, o desenvolvimento igualou-se a crescimento econômico por representar a própria essência do contexto da época.

A redução sofrida pelo desenvolvimento a alguns poucos componentes econômicos, segundo Arbix e Zilbovicius (2001), não só o transformou em coadjuvante dos processos de crescimento da produtividade, como levou o debate acerca do desenvolvimento a esvaziar "completamente seu conteúdo de busca de um ordenamento civilizado da vida em sociedade" (Arbix e Zilbovicius, 2001, p.56). É necessário perceber que, de forma mais ampla, conforme salienta Coriolano (2003), há hoje uma concordância mundial na compreensão do desenvolvimento enquanto uma ideia mais exigente que o simples conceito de crescimento econômico.

A forte carga ideológica e imperialista implícita no discurso desenvolvimentista é outro ponto amplamente destacado por diversos trabalhos que se prestam a discutir o tema de forma crítica. Nesse sentido, aponta-se que o modelo de desenvolvimento proposto pelos estadunidenses no início da década de 1950 era algo desejável a todos os demais países, na medida em que se intentava disseminar este modelo como o único possível, totalmente controlável, a-histórico, e que desconsiderava a realidade e especificidade dos diversos espaços em que ocorria. (FARIA, 2006; CORIOLANO, 2003). Os planos e projetos de desenvolvimento formulados à época refletiam tal situação, já que, como aponta Santos (2005), foram

concebidos e implementados a partir de cima (top-down development), com base em políticas traçadas e implementadas por agências tecnocráticas nacionais e internacionais sem a participação das comunidades afetadas por essas políticas (SANTOS, 2005, p.45).

Assim, é essencial visualizar a existência das diferentes teorias e propostas que, ao longo das últimas décadas, se prestaram a abordar o tema: desde aquelas centradas na ideia de crescimento da produção e do consumo, até aquelas que propõem novos rumos frente à abordagem tradicional. Isso denota que este tema vem sendo debatido há bastante tempo dentro e fora do âmbito das Ciências Sociais, em que se buscou, sobretudo, discutir suas (im)possibilidades teóricas e principais problemas a ele relacionados. 
Assim, diante das principais construções e divergências em torno do desenvolvimento e de sua já relatada ligação com o crescimento econômico, agrega-se à discussão a possibilidade que Cardoso (1993) denominou de um "outro desenvolvimento"12. Esta alternativa, por se posicionar contra toda uma orientação econômica e política do século XX e por ter como princípio motivador uma nova utopia ${ }^{13}$, naturalmente, excitava não apenas a imaginação dos povos oprimidos e afligidos pelas necessidades materiais, mas também despertava o interesse do pensamento social e econômico das nações industrializadas (CARDOSO, 1993). Dessa forma, as práticas e teorias que desafiam o capitalismo são, frequentemente, qualificadas como alternativas. Nestes mesmos termos, fala-se de economias alternativas, globalizações ${ }^{14}$ alternativas, desenvolvimento alternativo e, em específico, dentro do contexto deste trabalho, na possibilidade da construção de um turismo alternativo.

Santos (2005), por sua vez, contribui para o debate ao questionar a conveniência política e teórica do uso deste adjetivo, uma vez que: "qualificar algo como alternativo implica, desde logo, ceder terreno àquilo a que se pretende opor, o que, assim, reafirma seu caráter hegemônico" (SANTOS, 2005, p.26). Nesse sentido, nem sempre designar algo como alternativo implica, de fato, na superação de velhos paradigmas, como não implica, do mesmo modo, na proposição da prática de novos caminhos e de adaptações aos modelos que se tornaram predominantes e os quais se almeja modificar.

Bresser-Pereira (2006) sugere, diante dos inúmeros adjetivos atribuídos ao desenvolvimento, que seu uso desprovido de qualquer adjetivo ou o que o autor denomina de desenvolvimento humano seria, simultaneamente, o gênero que incluiria as formas econômica, social, política e ambiental e sua forma normativa. Contudo, ao invés de uma mudança na linguagem, com o acréscimo ou a supressão de um determinado adjetivo, "o que se exige no inicio de uma interrogação que procura teorizar e tornar visível o espectro de alternativas é formular a pergunta óbvia: alternativo em relação a quê?' (SANTOS, 2005, p.27). Ou seja, ao qualificar o desenvolvimento como alternativo, e, por exemplo, algumas possibilidades de se promover o turismo como formas alternativas dessa atividade, deve-se, primeiramente, questionar quais são os valores e práticas capitalistas que esses modelos criticam e procuram superar. Por mais que tais propostas lidem com aspirações legítimas e necessárias, elas acabam por se localizar na linha fina e paradoxal da aceitação do desenvolvimento como uma categoria universal ${ }^{15}$.

É possível pensar, então, o desenvolvimento fora do âmbito do desenvolvimento capitalista? É factível pensar em uma abordagem de desenvolvimento e mesmo de uma proposta de turismo desvinculada do paradigma do mercado?

Mesmo não havendo respostas imediatas para essas perguntas, chegam-se a algumas breves conclusões. Souza (1993) contribui com algumas pistas de como seria essa possibilidade ao afirmar que:

Para romper com a heteronomia embutida, como uma de suas dimensões, no projeto de modernidade, não se pode definir o conteúdo 
da ideia de desenvolvimento de modo "fechado", ainda que de forma aparentemente alternativa às visões mais convencionais (SOUZA, 1993, p.09).

Dessa forma, a superação de velhos conceitos (e simultaneamente de teorias e estratégias) de desenvolvimento por outros mais novos deve-se posicionar além de sua história habitual, em que certas visões fechadas foram substituídas por outras igualmente fechadas (SOUZA, 1993). Nestas visões, prevaleceu um explícito comprometimento etnocêntrico em relação ao Ocidente e, consequentemente, segundo Souza (1993), o que se observou nas mais diferentes abordagens do desenvolvimento, das teorias de modernização e do crescimento, passando pelos enfoques redistribution with growth e da satisfação de necessidades básicas, ao sustainable development (em sua usual acepção de um "capitalismo ecológico e domesticado") e ao neocepalismo ("transformação produtiva com equidade"), foram apenas exemplos mais atuais da renovação do discurso capitalista.

É necessário, assim, conforme salientam os autores que defendem este argumento, chamar a atenção para o fato de grande parte das abordagens direcionadas ao desenvolvimento - que refletem em diversos momentos as abordagens presentes nos trabalhos de turismo - apresentarem uma visão fechada de desenvolvimento, claramente baseada em uma concepção "eurocêntrica" da realidade. As "epistemologias do Sul"16, nos moldes propostos por Santos (2009), vão de encontro à noção fechada e unívoca de desenvolvimento, representada nas chamadas "epistemologias do Norte". Dessa forma, as epistemologias do Sul visam

[...] recuperar os saberes e práticas dos grupos sociais que, por via do capitalismo e do colonialismo, foram histórica e sociologicamente postos na posição de serem tão só objeto ou matéria-prima dos saberes dominantes, considerados os únicos válidos (SANTOS, 2009, p.11).

As teorias do desenvolvimento, sem considerar as experiências dos países não ocidentalizados, a exemplo das epistemologias do Norte, ao serem maximizadas, a partir da exportação de um modelo fechado de desenvolvimento, evidenciam a negligência com relação aos outros saberes existentes nestes contextos (SANTOS, 2009). Ao contrário das epistemologias do Norte, que, segundo este argumento, embasam a visão tradicional de desenvolvimento, Santos (2009) explica que as epistemologias do Sul procuram incluir o máximo das experiências de conhecimento do mundo. As experiências advindas do Norte, bem como suas teorias e ideologias, só caberiam, assim, nas epistemologias do Sul, depois de reconfiguradas.

Não há, dessa maneira, como negar as contradições entre Norte e Sul, bem como, para efeito ilustrativo, é preciso citar, em especial, os conhecimentos rivais que se encontram envolvidos nesta relação. Ou seja, é necessário perceber que o Norte tende a negar a validade ou mesmo a existência de conhecimentos alternativos ao 
conhecimento científico - conhecimentos populares, indígenas, camponeses etc. - a fim de transformá-los em matéria-prima para a conformação do conhecimento científico (SANTOS, 2007). Este argumento é correntemente utilizado, inclusive, em abordagens alheias ao modelo tradicional de turismo, como aquelas denominadas comunitárias ou de base local.

A urgência da construção de outro desenvolvimento, tendo em vista as limitações do conceito de desenvolvimento econômico, fez com que conceitos como os de qualidade e condições de vida fossem incorporados pelo termo desenvolvimento.

Ao se trabalhar com a ideia de desenvolvimento, portanto, é fundamental compreender que ela não se refere apenas à esfera da economia. O necessário é entender quais aspectos econômicos devem ser tomados em função do desenvolvimento. É importante, também, pensar em uma abordagem de desenvolvimento centrada no homem, e voltada para, como coloca Santos (2009), a promoção de um diálogo horizontal entre saberes a favor do surgimento de novas epistemologias. Porém, não é algo simples. Pelo contrário, suscita uma revolução de ideias e práticas sociais, que passam a orientar as pessoas e as organizações para produção e consumo partilhados (CORIOLANO, 2003b).

A construção de uma nova percepção de desenvolvimento, fora do âmbito do desenvolvimento capitalista e dos preceitos do mercado, necessita então, segundo a corrente que defende este argumento, de uma urgente descentralização teórica. Ao buscar romper com uma teoria fechada de desenvolvimento, Souza (1993) sugere que é necessário,

ao mesmo tempo, o esforço de formulação de uma teoria "aberta": ao invés de definir de uma vez por todas (explícita ou, como acontece com mais freqüência, implicitamente) o que seja desenvolvimento, cabe tão somente (o que porém, não é tão pouco) extrair um princípio norteador (SOUZA, 1993, p. 10).

Para além do excesso de adjetivos que pouco acrescentaram à ideia de desenvolvimento e dos paradigmas que ainda o amarram aos preceitos do mercado, acredita-se ser necessário vislumbrar princípios e práticas que contribuam com a desconstrução dessa percepção de desenvolvimento. Visualizar princípios como autonomia $^{17}$ e respeito, podem, por sua vez, propiciar uma base de respeito ao direito de cada coletividade de estabelecer, segundo as particularidades de sua cultura, 0 conteúdo concreto (sempre mutável) do desenvolvimento: as prioridades, os meios, e as estratégias.

Dentro da possibilidade de compreensão do desenvolvimento a partir de outro embasamento que não o calcado nos pressupostos unicamente econômicos, cabe citar a proposta trabalhada por Sen (2000), na qual se compreende o desenvolvimento como um processo de expansão das liberdades concretas que as pessoas desfrutam. Assim como anteriormente apontado, o enfoque nas liberdades humanas, como proposto pelo 
autor, contrasta com as visões mais restritas de desenvolvimento, como aquelas que o associam estritamente ao crescimento do PNB, ao aumento das rendas pessoais, à industrialização, ao avanço tecnológico ou à modernização social etc. Nessa visão de desenvolvimento, tais variáveis assumem outra importância à medida que são consideradas como um meio de expandir as liberdades desfrutadas pelas pessoas.

A perspectiva do desenvolvimento como liberdade, ao contrário de algumas das propostas que buscam criar alternativas ao desenvolvimento tradicional, visa proporcionar uma compreensão mais ampla e inclusiva dos mercados, em contraste àquelas que frequentemente são mencionadas quando se busca unicamente defender ou menosprezar os mecanismos de mercado. Ou seja, o enfoque de desenvolvimento discutido por Sen (2000), em uma visão particular, não despreza nem defende os mecanismos do mercado, mas posiciona-se além, ao acreditar que, por meio deles, torna-se possível alargar as liberdades reais que uma pessoa goza. A liberdade de participar nas trocas econômicas assume, assim, um lugar básico na vida social, segundo o autor referido.

Dessa maneira, tal abordagem, por meio de um enfoque amplo, busca integrar considerações econômicas, sociais e políticas, tendo como premissa básica a importância da liberdade humana em geral e o estímulo à condição de agente do indivíduo enquanto sujeito ativo de mudanças e não somente como receptor passivo de benefícios.

A expansão da liberdade representa, assim, o fim prioritário e, simultaneamente, o meio principal do desenvolvimento, segundo o enfoque construído por Sen (2000). Desenvolver, neste sentido, consistiria na remoção de vários tipos de restrições que deixam às pessoas poucas escolhas e poucas oportunidades para exercerem suas ações de forma racional (SEN, 2000). Para o autor, a promoção do desenvolvimento deve possibilitar a retirada das principais fontes de privação de liberdade: pobreza, carência de oportunidades econômicas, intolerância ou interferência excessiva de Estados repressivos etc. Nesse sentido, o crescimento econômico não é tratado como um fim em si mesmo, mas deve, por outro lado, possibilitar a promoção da vida que se deseja construir e das liberdades que cada indivíduo usufrui.

É necessário esclarecer que, conforme aponta Sen (2000), as liberdades não são apenas os fins primordiais do desenvolvimento, mas também os meios principais, sendo denominados respectivamente de "papel constitutivo" e "papel instrumental". Dentro dessa proposta, o autor define cinco tipos distintos de liberdade, vistos sob uma perspectiva instrumental, sendo elas: (1) liberdades políticas; (2) facilidades econômicas; (3) oportunidades sociais; (4) garantias de transparência; e (5) segurança protetora. Dessa forma, cada um desses tipos distintos de direitos e oportunidades ajuda a promover a capacidade geral de uma pessoa e contribui, assim, com o aumento da liberdade humana como um todo. Eles podem, ainda, atuar complementando-se mutuamente. 
A proposta de se compreender o desenvolvimento como expansão de liberdades dirige, assim, a atenção para os fins que o tornam importante, evitando restringir essa visão a alguns dos meios que, entre outras coisas, desempenham um papel relevante no processo. Nesse sentido, as pessoas têm de ser vistas como ativamente envolvidas, sendo dada a oportunidade no processo de conformação de seu próprio destino e não apenas como beneficiárias passivas das vantagens dos programas de desenvolvimento. Sen (2000), a partir de sua abordagem e em virtude de sua forma de compreender o papel dos atores dentro do processo de desenvolvimento, dando destaque à questão da participação, salienta, assim, que

\begin{abstract}
se um modo de vida tradicional tem de ser sacrificado para escapar-se da pobreza devastadora ou da longevidade minúscula (que é como vivem muitas sociedades tradicionais há milhares de anos), então são as pessoas diretamente envolvidas que têm de ter oportunidade de participar da decisão do que deve ser escolhido (SEN, 2000, p.47).
\end{abstract}

Vistos alguns dos principais traços da abordagem de Sen (2000), o próprio autor questiona se há realmente uma diferença substancial entre a análise do desenvolvimento centrado no "crescimento do produto per capita" (como o PNB per capita) e a que se volta à expansão da liberdade humana. Para defender seu ponto de vista, Sen (2000) baseia-se em duas razões bem distintas, que consistem no que ele denomina "aspecto do processo" e "aspecto da oportunidade".

O primeiro refere-se à participação nas decisões políticas e na escolha social, sendo a proposta do desenvolvimento como liberdade considerada não apenas meio do desenvolvimento, mas também um fim deste mesmo processo. Já o aspecto da oportunidade diz respeito à possibilidade que têm as pessoas de obter resultados por elas valorizados (e que tenham razões para valorizar as liberdades das quais usufruem), incluindo a liberdade de viver longamente, de ter um emprego que valha a pena, de viver em comunidades pacíficas etc.

Ambos os elementos são, assim, pontos que a proposta do desenvolvimento como liberdade - ao contrário do desenvolvimento centrado no crescimento dos indicadores econômicos - não só leva em consideração, mas os toma enquanto pontos centrais de sua análise.

Possuir mais liberdade significa, então, melhorar o potencial das pessoas para cuidar de si mesmas e, consequentemente, influenciar o mundo, por meio do estímulo da condição de agente autônomo enquanto alguém que age e ocasiona mudança. Conforme ressalta Abramovay (1998), acerca da visão defendida por Sen (2000), em linhas gerais, é dada ênfase à ampliação do horizonte da vida das pessoas, sem desprezar a base material do processo de desenvolvimento. Essa análise, apesar de representar uma abordagem particular acerca do processo de desenvolvimento, demonstra sua validade a partir do momento em que revela uma nova possibilidade de se interpretar o tema. O foco do desenvolvimento, a partir da análise de Sen, volta-se, portanto, para as pessoas, para o que se torna possível modificar em suas vidas, em um 
sentido de melhora, de expansão das liberdades concretas das mesmas. A perspectiva de Sen (2000), em virtude da nova abordagem proposta acerca do desenvolvimento e do processo que ele enseja, é comumente referenciada em trabalhos na área de turismo com o intuito de proporcionar a reflexão sobre novos modelos de promoção da atividade em concordância com estes preceitos.

Neste contexto, é necessário apresentar, segundo Reis (2005), três perspectivas predominantes que permitem entender os processos históricos e de desenvolvimento, que se desdobram, por sua vez, em quatro projetos políticos (liberal -conservador, liberal democrático, social-democrático e projeto político ecológico) "que disputam a hegemonia em torno da proposição de estratégias para a promoção do desenvolvimento" (REIS, 2005, p.15). No entanto, para o presente artigo, optou-se por se ater, de forma mais direta, apenas às dimensões de análise dos processos de desenvolvimento, deixando de lado, por ora, a discussão realizada pelo autor acerca dos quatro projetos políticos resultantes destas perspectivas ${ }^{18}$.

Vale destacar que o autor deixa claro que, ao abordar as três formas de interpretação dos processos de desenvolvimento, ele está se referindo a pontos extremos, "de modo que também é possível perceber diversas interações entre essas maneiras de se entender os processos de desenvolvimento, bem como de se construir estratégias para sua promoção" (REIS, 2005, p.08).

Esta breve exposição se torna interessante e de grande utilidade para 0 presente trabalho, na medida em que irá revelar, por exemplo, onde os enfoques de desenvolvimento identificados a partir do turismo se enquadram na análise apresentada por Reis (2005). Ou seja, será possível questionar, a partir da apresentação destas abordagens, como cada um dos enfoques identificados, e que serão discutidos a seguir, relaciona-se às três possibilidades de leitura dos processos de desenvolvimento, a saber, o socialismo, o capitalismo e a perspectiva ecológica. Reis (2005) analisa, então, como elas interpretam e apresentam estratégias voltadas, por exemplo, para tornar a distribuição de riqueza um meio de promover a justiça social.

Para a perspectiva que se aproxima do socialismo, esta questão estaria relacionada à aquisição de mais democracia, ou seja, "um acesso mais equitativo às instâncias de poder e aos processos decisórios, o que garantiria a manutenção de mecanismos institucionais de redistribuição dos acréscimos ao estoque de riqueza existente, impedindo a sua reconcentração" (REIS, 2005, p.08).

$\mathrm{Na}$ segunda perspectiva, que se aproxima da defesa do capitalismo, distribuir riqueza como um mecanismo capaz de promover a justiça social, relaciona-se a

criar instituições que permitam uma maior eficiência dos mecanismos de mercado, levaria ao aprofundamento da divisão social do trabalho, o que, por sua vez, permitiria a socialização dos ganhos de produtividade oriundos da especialização produtiva, pela participação 
nas redes, democráticas por princípio, de trocas mercantis. (REIS, 2005, p.08)

Por fim, numa perspectiva ecológica, Reis (2005) afirma que propor a transformação das formas prevalecentes de produção e consumo, a fim de torná-las compatíveis com o funcionamento dos diversos ecossistemas terrestres,

implicaria promover-Ihes a sustentabilidade, isto é, permitiria-Ihes conjuntamente a sua manutenção, reprodução e transformação, o que corresponderia a garantir o equilíbrio entre eles e, portanto, a melhora da qualidade de vida dos grupos humanos e a possibilidade de sua existência no futuro (REIS, 2005, p.08).

Nesse sentido, cabe introduzir, ainda que superficialmente, a noção de "representações do desenvolvimento", trabalhada pelo autor e que indiretamente contribui e relaciona-se ao conteúdo deste artigo. A partir do que foi exposto acima, Reis (2005) traz duas principais conclusões: primeiramente, as "representações do desenvolvimento, pelo menos as aqui consideradas, e suas diversas possibilidades de interação, padecem do fato de conter, no seu conjunto, uma linha muito tênue entre o que é e o que deve ser (...)" (REIS, 2005, p.08). Em seguida, pode-se concluir, segundo o autor, que "processos de desenvolvimento são processos históricos, mas nem todo processo histórico coincide com processos de desenvolvimento, os quais possuem, no seu cerne, algo relativo à idéia de melhora, melhora da condição da existência humana" (REIS, 2005, p.08).

A dimensão de melhora contida no desenvolvimento é também constantemente ressaltada nas menções feitas ao tema por meio da literatura de turismo. Associar turismo ao desenvolvimento, como antes mencionado, é, normalmente, representá-lo por meio de uma estratégia que se presta a promover o desenvolvimento e, dessa maneira, promover alguma forma de melhora advinda de sua instalação e crescimento.

Ao fim, e ainda relacionado a estas três possibilidades de leitura dos processos de desenvolvimento, Reis (2005. P.09) conclui que "no primeiro caso, houve melhora apenas para alguns, às custas dos demais; no segundo, houve melhora, mas apenas para aqueles que fizeram por onde; e no terceiro, piorou para todos, para os que estão vivos e para os que estão por nascer".

Buscou-se, neste tópico, portanto, resgatar algumas abordagens de autores que buscam discutir os problemas e as diversas possibilidades de se interpretar e compreender o desenvolvimento. Nesse sentido, julgou-se necessário introduzir algumas discussões recorrentes acerca do desenvolvimento e das questões que ele implica, como, por exemplo, a já discutida associação com o crescimento econômico e a possibilidade de construção de uma proposta alternativa ao modelo prevalecente de desenvolvimento. Assim, ressalta-se que alguns dos pontos aqui discutidos, apesar de muitas vezes extrapolarem o ponto de vista apresentado pelas obras de turismo que 
discutem a relação estabelecida com o desenvolvimento, contribuem e auxiliam no entendimento de traços fundamentais deste processo.

\section{Abordagens de Desenvolvimento no Turismo}

Por abordagem, compreendem-se as diferentes formas de se conceber e representar o tema do desenvolvimento, presente em estudos, planos e documentos consultados e que tratam do turismo. Ou seja, quais são as formas de se nomear, qualificar e significar o desenvolvimento pelo turismo e que são identificadas, reconhecidas e amplamente utilizadas pelos estudos desta área. A "abordagem" ou "enfoque" consistiria, então, nas formas pelas quais o turismo, por meio de suas obras e documentos, é capaz de compreender a relação estabelecida com os processos de desenvolvimento.

Dessa maneira, foram identificadas, a priori, três abordagens predominantes nos trabalhos de turismo, e que correspondem às referências direcionadas ao desenvolvimento do e pelo turismo, respectivamente, enquanto uma possibilidade de promovê-lo e relativo à qualidade do processo a ser desencadeado pela atividade. As abordagens identificadas foram classificadas como: utilitarista/econômica, sustentável e comunitária/local. Cabe destacar que, apesar de em certos momentos a abordagem do desenvolvimento estar implícita e diretamente relacionada a determinadas tipologias, essa não é uma associação simples de ser feita e nem se configura como propósito deste trabalho. A seguir são apresentadas as características principais de cada uma destas abordagens.

A abordagem utilitarista/econômica, identificada como umas das principais e mais recorrentes formas de se referir ao desenvolvimento dentre aquelas implícitas nos estudos de turismo, surge com maior frequência em análises que buscam ressaltá-lo em virtude de seu efeito multiplicador enquanto atividade econômica.

Como explicitado anteriormente nesse artigo, vale ressaltar que a dimensão econômica do desenvolvimento sempre foi a mais amplamente estudada e aceita no meio acadêmico, político e empresarial. Assim, mesmo que esse termo tenha passado por redefinições ao longo de sua trajetória, ao incorporar uma série de adjetivos que Ihes conferiram uma nova faceta, ainda assim a dimensão econômica continua a ser considerada fundamental para a melhoria das condições de vida dos indivíduos.

Assim, as teorias do desenvolvimento, inicialmente organizadas nos trabalhos da economia clássica, sempre tiveram seus critérios de definição e formas de mensuração do desenvolvimento centrados, sobretudo, na ampliação das diversas formas de renda e riqueza. Nesse sentido, Souza (1999) também enfatiza a abordagem econômica do desenvolvimento e aponta a existência de duas correntes de pensamento. A primeira delas considera o desenvolvimento como sinônimo de crescimento econômico. 
Para os economistas que associam crescimento com desenvolvimento, um país é subdesenvolvido porque cresce menos do que os desenvolvidos, embora possua recursos ociosos, como terra e mão-de-obra. Ele não utiliza integralmente os fatores de produção de que dispõe e, portanto, a economia expande-se abaixo de suas possibilidades (SOUZA, 1999, p.20).

Já a segunda corrente exposta por esse autor enxerga crescimento e desenvolvimento como ideias distintas. Essa corrente considera o crescimento uma condição indispensável para o processo de desenvolvimento, mas não uma condição suficiente. $\mathrm{O}$ crescimento é visto, então, como uma variação quantitativa, enquanto que o desenvolvimento requer mudanças qualitativas no modo de vida das pessoas. Essa noção requer mudanças nas estruturas econômicas, sociais, políticas e institucionais, com simultânea melhoria da produtividade e da renda média dos agentes envolvidos no processo produtivo.

Dessa forma, frequente em trabalhos que partem de uma base econômica e que buscam legitimação em documentos políticos, como exemplo o Plano Nacional de Turismo (PNT) ${ }^{19}$, esta abordagem, apesar de sua expressiva predominância, vem sendo recorrentemente questionada quanto aos seus limites, sobretudo do ponto de vista social e ambiental. A própria existência de outros enfoques de desenvolvimento demonstra, nesse sentido, novas formas de resistência e contestação em relação à predominância desta primeira.

A conformação de um discurso em torno do turismo, que confere ao mesmo o status de "passaporte para o desenvolvimento", possui relação direta com a abordagem em destaque. Assim, como ressalta Ouriques (2008), "o turismo desponta nas regiões periféricas como a mais recente promessa de desenvolvimento e, em alguns discursos (inclusive acadêmicos), como a única chance de alcançar o tão almejado desenvolvimento" (OURIQUES, 2008, p.13). Esta concepção de desenvolvimento, conforme identificado por meio das obras e estudos que tratam do turismo, é, pois, uma das possibilidades de se compreender e analisar a relação estabelecida entre o desenvolvimento e o turismo. Contudo, é perceptível que tal enfoque não dá conta de abarcar outros aspectos presentes na promoção do turismo, como aqueles relacionados às dimensões humana, cultural e social. Essa limitação consiste, por sua vez, em um dos principais pontos de críticas e contestações por parte da literatura, pois, assim como salienta Moesch (2001), "o turismo é um processo sociocultural, ultrapassando o entendimento enquanto função de um sistema econômico" (MOESCH, 2001, p.21).

A abordagem sustentável de desenvolvimento, por sua vez, conforme enfatizam vários autores, surge a partir de meados da década de 1980, sendo associada "a uma mudança de enfoque na definição da problemática ambiental, de visões eminentemente preservacionistas dos anos de 1960 e 1970, à associação entre crescimento econômico e preocupação ambiental' (COSTA, 2008, p.80). Dessa maneira, ao romper com o conflito que foi gerado entre os desenvolvimentistas e ecologistas, o conceito de desenvolvimento sustentável apropria-se de uma suposta obviedade: "a de desenvolver e preservar" (LOBO, 2001, p.15). 
Em termos conceituais, de acordo com Esteva (2000), houve, em meados do século XX, uma revolta generalizada contra a "camisa-de-força" das definições econômicas do desenvolvimento, que restringia suas metas a indicadores quantitativos e relativamente irrelevantes. A partir daquele momento, questionava-se até que ponto era possível explicar o desenvolvimento empregando apenas termos econômicos. Dessa maneira, um arsenal crítico começa a minar os pilares de sustentação das tradicionais teorias de desenvolvimento econômico (LOBO, 2001).

Como reflexo deste processo, desde o início da década de 1990 o termo sustentável passa a ser amplamente utilizado no debate sobre o desenvolvimento, atingindo diversos setores e atividades econômicas, dentre elas, o turismo. Por terem se intensificado as pesquisas que analisam os impactos socioespaciais do turismo, verificando que a atividade turística acaba, muitas vezes, alavancando um processo de desenvolvimento altamente impactante, ambiental e socialmente, cresce, também de maneira significativa nos últimos anos, o debate sobre as formas de turismo que buscam se contrapor ao turismo convencional ou de massa.

Em especial, no que se refere aos estudos voltados para o turismo, a dimensão sustentável do desenvolvimento é comumente associada à atividade enquanto um adjetivo que qualifica e agrega valor, sobretudo comercial, à mesma. Ou seja, o turismo sustentável corresponde a um termo específico que denota a aplicação do desenvolvimento sustentável ao contexto particular do turismo. Como acrescenta Candiotto (2009), "com a emergência da ideia de desenvolvimento sustentável, o termo turismo sustentável vem cada vez mais ganhando espaço no debate acadêmico, bem como no marketing turístico" (CANDIOTTO, 2009, p.02).

Percebe-se que, assim como no conceito de desenvolvimento sustentável, o turismo sustentável baseia-se na dimensão econômica e incorpora timidamente as dimensões ambiental, social e cultural, entendendo-as, na visão de Candiotto (2007) "como oportunidades e recursos para a continuidade da atividade turística" (CANDIOTTO, 2009, p.02). Nesse contexto, a categoria de sustentável é muito mais um rótulo que de fato uma orientação para a promoção da atividade turística. Na visão defendida por Butler (1998), o turismo adquire o status de "sustentável" para que possa ser vendido, uma vez que traz vantagens econômicas nas relações públicas e no marketing, ou seja, dá lucros.

A terceira das abordagens identificadas - comunitária/local - é apropriada pelos estudos de turismo como uma "nova" orientação, que visa transformar o caráter estritamente predatório e econômico apresentado pela atividade (RODRIGUES, 1997; BENEVIDES, 1997). Em síntese, a proposta baseia-se no conceito de desenvolvimento local como princípio orientador para a construção de um modelo de promoção do turismo, distinto do prevalecente. A abordagem de desenvolvimento identificada como comunitária/local, além de agregar valor ao tipo de turismo que inspira, é apresentada pelos trabalhos que a abordam como um "guia de orientação" para a construção de "outro" modelo de promoção da atividade turística, direcionada para a escala local e focada nos sujeitos sociais que participam deste processo. 
Vale esclarecer que se convencionou trabalhar as dimensões comunitária e local conjuntamente, dentro de uma única abordagem, já que, ainda que os trabalhos possam se referir à essas dimensões de forma separada, elas partem, normalmente, de um mesmo conceito de desenvolvimento, e, portanto, possuem objetivos e diretrizes similares. Em um mesmo sentido, Reis (2008) considera que, em termos de territorialidade, "a designação desenvolvimento local, embora não exclua, pode abranger ou até se confundir com desenvolvimento urbano, desenvolvimento rural e desenvolvimento comunitário" (REIS, 2008, p.07). De forma complementar, o mesmo autor acrescenta que o desenvolvimento local pode, ainda, ser pensado em termos de sentidos de melhora, além de poder acontecer de forma integrada, sustentável e endógena. (REIS, 2008).

O turismo, associado à abordagem local de desenvolvimento e identificado como alternativo, passa a ser compreendido como um estilo contraposto às tendências e aos padrões dominantes. Há que se refletir, contudo, se o desenvolvimento local, a partir de sua apropriação pelos estudos turísticos, surge apenas como mera adaptação do modelo econômico convencional ou se de fato se contrapõe à ordem econômica vigente.

Propor o desenvolvimento com base local "significa contrariar a racionalidade econômica hegemônica vigente e fortalecer o que Milton Santos designa por 'contrafinalidades' que são localmente geradas [...]' (RODRIGUES, 1997, p.58). Ou seja, torna-se necessário, para tanto, revisitar e questionar diversos conceitos prevalecentes no modelo tradicional, como, por exemplo, o conceito de eficiência, que se associa à noção de maximização da produtividade. Complementarmente, o desenvolvimento com base local, para o turismo, na visão de Coriolano (2003), representaria, então, o

processo de mudança de mentalidade, de câmbio social, e de troca de eixo na busca do desenvolvimento, por isso se orienta para o desenvolvimento de médias, pequenas e micro-empresas, tendo em vista socializar as oportunidades e promover o desenvolvimento na escala humana (CORIOLANO, 2003, p. 25).

A proposição de um turismo local ou de base comunitária passaria, então, pela alusão à mesma dinâmica de participação dos sujeitos locais e de apropriação das práticas sociais locais contidas no conceito de desenvolvimento local. Novamente, percebe-se que o turismo, em relação ao contexto atual de promoção do desenvolvimento, se insere enquanto uma estratégia voltada para este fim.

Acredita-se que a análise do turismo, por meio de suas abordagens de desenvolvimento, qualifica seu entendimento para além das tipologias da área, tidas, normalmente, como uma maneira de classificar a atividade, e sendo, algumas vezes, apresentadas sob a forma de via alternativa para a promoção da atividade turística. É importante lembrar que, na verdade, elas podem ser entendidas como reflexos de abordagens do desenvolvimento existentes e que influenciam muitas outras atividades econômicas, assim como ocorre no turismo. 


\section{Planejamento Turístico e suas perspectivas}

$\mathrm{Na}$ mesma intensidade com que tem sido comum referir-se ao turismo a partir de seu propalado poder de desenvolvimento, recorre-se ao planejamento como instrumento imprescindível para o bom funcionamento da atividade turística.

Ao se abordar o turismo e sua relação com o desenvolvimento, quase de imediato é suscitada por grande parte dos estudiosos da área a discussão sobre a necessidade direta do planejamento. Entre as várias definições existentes de planejamento, cita-se a utilizada por Lohmann e Netto (2008), que o conceituam, em uma perspectiva abrangente, como 0

[...] processo que visa, a partir de uma situação dada, a orientar o desenvolvimento turístico de um empreendimento, local, região, município, estado ou país, tendo como meta alcançar objetivos propostos anteriormente ou durante a própria elaboração do planejamento (LOHMANN e NETTO, 2008, p.129).

Apesar dos benefícios gerados para uma comunidade, o turismo pode, em virtude de seu expressivo crescimento, provocar efeitos mais nocivos do que benéficos. É sempre importante lembrar que o turismo traz custos e benefícios econômicos e não econômicos para as comunidades afetas por essa atividade. Goeldner et al. (2002) ressaltam que o turismo mal planejado e mal desenvolvido pode trazer sérios problemas. O planejamento da atividade turística, nesse sentido, é reconhecido como um poderoso instrumento de fomento ao desenvolvimento socioeconômico de uma comunidade.

Assim, observa-se que, invariavelmente, se justifica o "sucesso" de um determinado destino turístico ao exercício do planejamento naquela localidade. Dessa forma, é perceptível também que, se por outro lado, o turismo gera impactos negativos, concentra seus benefícios em uma pequena parcela da população e pouco acrescenta para a qualidade de vida de uma comunidade, culpa-se, instintivamente, a falta ou o fracasso do planejamento. Como mencionado no curso virtual sobre "Turismo e Meio Ambiente" ${ }^{20}$, oferecido pelo Ministério do Turismo em convênio com a Fundação Universa: o problema reside na falta de planejamento. Ou seja, o uso do planejamento como ferramenta para organizar e controlar o incremento do turismo é, de uma forma geral, apontado como parte imprescindível e indissociável desta atividade.

Sobre o papel do planejamento para a atividade turística, segundo Solha (2004), no turismo, "as preocupações em se estabelecer políticas para o setor só aparecem quando este adquire importância econômica, ou quando começa a causar transtornos" (SOLHA, 2004, p.09). Anteriormente a estas duas situações, a autora reitera que a atividade se caracteriza pela espontaneidade, com pouco ou nenhum controle de seu desenvolvimento, prevalecendo apenas as leis de mercado. Estas conclusões reafirmam e legitimam o uso do planejamento, uma vez que as situações 
apontadas e que justificam a elaboração de uma política de turismo consistem em aspectos corriqueiros ao processo de promoção da atividade turística. Contudo, percebe -se que, via de regra, a importância econômica é, na maioria dos casos, o principal motivador do uso do planejamento quando associado à atividade.

Para uma melhor compreensão de como o planejamento é abordado no âmbito da atividade turística, cabe citar cinco principais tradições nesta área, segundo Wall (2000) e Getz (1991). A primeira, denominada boosterism, consiste em uma promoção do desenvolvimento e, dessa forma, não se configura como uma forma de planejamento. A segunda tradição compreende o turismo como uma atividade econômica, dando enfoque especial em seu processo de promoção e em seu marketing. A terceira foca, sobretudo, os aspectos espaciais do turismo e o planejamento dos recursos físicos. A quarta tradição vem sendo amplamente discutida na atualidade e refere-se ao planejamento comunitário, que estipula que cada local tenha 0 controle dos processos de planejamento e seus objetivos. Para tanto, utilizam-se conceitos como planejamento social, participativo e comunitário e capacidade de carga. A quinta, que propõe uma abordagem integrada e sistemática, prevê que objetivos, políticas e estratégias devem estar fundamentados em uma total compreensão de como o sistema turístico funciona.

Cabe ressaltar que, assim como na apresentação das abordagens de desenvolvimento presentes no estudo do turismo, estas tradições visam apenas permitir uma melhor visualização e organização das diversas perspectivas em torno do planejamento turístico. O que importa observar, neste momento, é qual a relação estabelecida entre as principais perspectivas de planejamento turístico e as abordagens de desenvolvimento anteriormente identificadas. Espera-se, com isto, traçar um paralelo que encontre pontos de convergência entre ambos os enfoques.

\section{Estabelecendo a relação: abordagens de Desenvolvimento x Planejamento}

No intuito de contrastar a relação estabelecida entre as principais perspectivas de planejamento turístico e as abordagens de desenvolvimento identificadas por meio da literatura de turismo, sugere-se a leitura de tais informações a partir de um quadro síntese, disposto a seguir (Quadro 1). Nesse quadro estão relacionadas as abordagens de desenvolvimento selecionadas, bem como suas respectivas características fundamentais e os preceitos das principais formas de compreensão do planejamento no âmbito do turismo.

Vale destacar a proximidade estabelecida entre os conteúdos de ambos os elementos, no sentido de evidenciar a estreita relação entre o planejamento e os desdobramentos advindos dos processos de desenvolvimento. Ainda que, de início, seja difícil estabelecer uma correlação entre as noções dispostas no quadro, em virtude da não correspondência numérica entre eles, é possível perceber que as abordagens de desenvolvimento exercem uma clara influência entre as perspectivas de planejamento turístico e vice-versa.

Nesse sentido, é de suma importância introduzir, mesmo sumariamente, as principais fases da política pelas quais, mundialmente, passaram a atividade turística, 
abrangendo, para tanto, o período de 1950 até o momento atual. O primeiro momento, que compreende o período de 1950 a 1970, caracterizou-se pela expansão do turismo de massa, quando eram comuns as políticas de fomento, cujo objetivo principal era o aumento do fluxo de visitantes. Em seguida, entre os anos de 1970 a 1985, observou-se o início de um período no qual as políticas começavam a identificar o turismo como agente de desenvolvimento. Em virtude desse reconhecimento, verificou-se um aumento do envolvimento governamental e o consequente investimento em infraestrutura nas localidades definidas como turísticas. Do ano de 1985 até o momento presente, entra-se na terceira e atual fase, um novo momento, estimulado por questões que atualmente se encontram em voga na sociedade e no meio científico e acadêmico. Observa-se uma maior preocupação com as temáticas ambientais, ao mesmo tempo em que se percebe um significativo aumento da competitividade, estimulando, por sua vez, um posicionamento responsável e profissional do mercado de turismo, no qual o Estado diminui sua interferência e procura assumir um papel de coordenação e estruturação da atividade. (SOLHA, 2002; OMT, 2001; HALL, 2001).

Quadro 1: Comparativo entre Abordagens do Desenvolvimento presentes na literatura de turismo X Perspectivas de planejamento turístico.

Table 1: Comparison of Approaches for Development of Tourism in the literature X Perspectives tourism planning.

\begin{tabular}{|c|c|c|c|c|}
\hline Abordagem & $\begin{array}{l}\text { Caracteristicas } \\
\text { principais }\end{array}$ & Estratégias propostas & $\begin{array}{c}\text { Perspectivas de } \\
\text { planejamento turístico }\end{array}$ & Caracteristicas principais \\
\hline \multirow[t]{2}{*}{ Econômica/utilitarista } & \multirow{2}{*}{$\begin{array}{l}\text { Enfoque excessivo } \\
\text { na dimensão de } \\
\text { melhora, sobretudo, } \\
\text { econômica, que o } \\
\text { desenvolvimento } \\
\text { pode vir a propiciar. }\end{array}$} & \multirow{2}{*}{$\begin{array}{l}\text { Estímulo à promoção do turismo } \\
\text { focando, sobremaneira, } \\
\text { aspectos como concorrência e } \\
\text { competiçấo, dando ênfase a sua } \\
\text { capacidade de gerar renda e } \\
\text { emprego. }\end{array}$} & Fomento ou impulsionista & $\begin{array}{l}\text { A atitude simplista de que o } \\
\text { desenvolvimento turístico é sempre bom e } \\
\text { proporciona, automaticamente, benefícios } \\
\text { para os anfitrízes. Os moradores das } \\
\text { destinaçő́es turísticas não estão envolvidos } \\
\text { na tomada de decisర̃es, no planejamento e } \\
\text { no processo politico do desenvolvimento } \\
\text { turístico. }\end{array}$ \\
\hline & & & Econômica/industrial & $\begin{array}{l}\text { Turismo como meio de promover } \\
\text { crescimento em áreas específicas. } 0 \\
\text { planejamento enfatiza os impactos } \\
\text { econômicos do turismo e sua utilização } \\
\text { eficiente para criar renda e empregabilidade } \\
\text { para determinadas regiôes ou comunidade. }\end{array}$ \\
\hline \multirow{2}{*}{ Sustentável } & \multirow{2}{*}{$\begin{array}{l}\text { Incorporação de } \\
\text { outras facetas do } \\
\text { desenvolvimento, } \\
\text { além da econômica, } \\
\text { como ambiental, } \\
\text { cultural e social. } \\
\text { Valorização dos } \\
\text { aspectos naturais e } \\
\text { histórico-culturais no } \\
\text { território. }\end{array}$} & \multirow{2}{*}{$\begin{array}{l}\text { Promover atividades, que } \\
\text { contemplem o incentivo à } \\
\text { promoção do desenvolvimento } \\
\text { que se baseia em uma } \\
\text { concepção que ultrapassa a } \\
\text { dimensão econômica, }\end{array}$} & Física/espacial & $\begin{array}{l}\text { O turismo é tratado como tendo uma } \\
\text { base ecológica e, consequentemente, seu } \\
\text { desenvolvimento deve ter por base certos } \\
\text { padrões espaciais, capacidades ou } \\
\text { limitações que minimizariam o impacto } \\
\text { negativo do turismo no ambiente físico. }\end{array}$ \\
\hline & & & Sustentável & $\begin{array}{l}\text { Uma forma integrada de planejamento } \\
\text { turístico que procura garantir, a longo prazo, } \\
\text { e com o mínimo de deterioração de } \\
\text { recursos, de degradação ambiental, de } \\
\text { rompimento cultural e de instabilidade } \\
\text { social, a segurança dos moradores. Tal } \\
\text { abordagem tende a integrar características } \\
\text { das tradiçóes econômicas, físico-espaciais } \\
\text { e comunitárias. }\end{array}$ \\
\hline Comunitária/local & $\begin{array}{l}\text { Enfoque direcionado } \\
\text { à escala do local, } \\
\text { privilegia a } \\
\text { participação das } \\
\text { populaçقes ao longo } \\
\text { do processo de } \\
\text { desenvolvimento. }\end{array}$ & $\begin{array}{l}\text { Contemplar aç̋es e projetos } \\
\text { que se baseiam no poder de } \\
\text { mobilização e engajamento dos } \\
\text { agentes sociais e a capacidade } \\
\text { dos mesmos em pensar o local } \\
\text { de forma integral, a fim de que } \\
\text { os recursos produtivos sejam } \\
\text { valorizados e transformados em } \\
\text { vantagens competitivas efetivas. }\end{array}$ & Comunitária & $\begin{array}{l}\text { Ênfase no contexto social e político no } \\
\text { qual o turismo ocorre. Defende um maior } \\
\text { controle local sobre o processo de } \\
\text { desenvolvimento. }\end{array}$ \\
\hline
\end{tabular}

Fonte: Baseado em Queiroz (2005), Hall (2001), Getz (1991) e Wall (2000). Adaptado pelos autores. Source: Based on Queiroz (2005), Hall (2001), Getz (1991) and Wall (2000). Adapted by the authors. 
No primeiro dos casos, nota-se a relação direta entre a noção de desenvolvimento econômico e a perspectiva de planejamento, que se volta para o incremento econômico do turismo. Acompanhando a mesma lógica que possibilitou o questionamento acerca dos limites ambientais do desenvolvimento econômico, cita-se o surgimento da noção de desenvolvimento sustentável e, com ela, perspectivas de planejamento que trouxeram como influência principal o discurso da sustentabilidade. Por último, cabe mencionar a aproximação entre a noção de desenvolvimento comunitário/local e a noção de planejamento comunitário, tendo como foco principal as relações que serão traçadas no âmbito do local.

Nota-se que a mesma lógica aplicável às abordagens presentes na literatura de turismo é estendida às perspectivas de planejamento turístico. $O$ esforço em construir e demonstrar a relação entre ambos os campos apresenta-se como uma tentativa de evidenciar a ampla influência das diferentes maneiras de se compreender e apreender a ideia de desenvolvimento.

Cabe destacar, contudo, que influenciada por diferentes áreas, contextos sociais e por interesses objetivos e, mesmo em certos momentos, não declaráveis, as abordagens de desenvolvimento acabam por consistir em elementos constantes e presentes na análise do turismo.

\section{Conclusões}

A menção à capacidade do turismo de atuar enquanto agente de desenvolvimento é algo largamente apontado nos trabalhos de turismo, fato que direciona para uma espécie de consenso compartilhado também nos meios político e empresarial. $O$ desenvolvimento turístico, assim como é utilizado pelos trabalhos da área, não distingue uma simples, mas importante diferença entre o desenvolvimento do e o desenvolvimento pelo turismo. Ou seja, o desenvolvimento do turismo nem sempre corresponde, de forma positiva, ao desenvolvimento pelo turismo, o qual ele mesmo pode vir a ser capaz de estimular. Apesar de se observarem, em vários contextos, altas taxas de crescimento do turismo, divulgadas como parte de seu desenvolvimento, não se pode dizer o mesmo sobre evidências de benefícios concretos para as populações envolvidas. Conforme ressalta Armendáriz e Serrano (2006), em alguns países em desenvolvimento, "mais de $2 / 3$ da renda do turismo internacional nunca chega à economia local devido a grande fuga de divisas" (ARMENDARIZ; SERRANO, 2006, p.47).

Vale destacar, então, a capacidade dual da atividade de proporcionar impactos tanto positivos quanto negativos para a comunidade receptora, uma vez que, para que os impactos sejam positivos, atrela-se a construção de um equilibrado e harmonioso processo de promoção do turismo ao exercício do planejamento turístico, nem sempre ao alcance das comunidades receptoras.

$\mathrm{O}$ uso do planejamento como instrumento fundamental e indispensável à construção de um desenvolvimento "harmonioso" gerado pela atividade é outro ponto de concordância, quase consensual, nos estudos da área de turismo. Cabe questionar, no entanto, até que ponto a dinâmica de promoção do turismo deverá necessariamente 
estar atrelada ao planejamento, paralelamente ao fato de que nem sempre é dada a oportunidade aos envolvidos neste processo, sobretudo aos grupos menos influentes, de tornar efetivo o uso desta ferramenta, que redundaria em mudanças na qualidade de vida destes atores.

Paralelamente, torna-se necessário apontar, na discussão acerca dos limites e possibilidades do turismo comunitário, que o termo alternativo ou a criação de adjetivos que visavam diferenciar o turismo de seu modelo tradicional, nem sempre significam, na prática, a conformação destas premissas. Assim como percebe Quintero (2006), "nas últimas décadas, a estrutura do turismo mudou para ecoturismo, turismo solidário, de aventura, social, entre outros, mas os problemas de fundo continuam a crescer notavelmente" (QUINTERO, 2006, p.72). Essa ponderação é fundamental para demonstrar também que, apesar dos inquestionáveis benefícios dessas novas formas de promoção do turismo, ainda pouco se contribui para amenizar os problemas básicos que ele mesmo gera.

Os princípios que são defendidos por estas propostas apresentam-se, assim, como aspectos recorrentes entre os diversos modelos de turismo ditos alternativos, independente da nomenclatura utilizada. Em diversos momentos, percebe-se que as modalidades de turismo intituladas comunitária, de base local e ecoturismo baseiamse em uma mesma orientação para construir as ações que visam à consolidação de um novo modelo de promoção do turismo. Todas elas aspiram a uma mudança significativa na ordem existente ao sugerirem a construção de uma atividade turística mais humana, igualitária e justa, e que se preocupa, sobretudo, com os grupos mais afetados por ela, pois, no modelo tradicional, são o de menor poder de decisão.

Em uma linha de raciocínio semelhante, cita-se o trabalho realizado por Souza (1997), em que é destacado que o turismo será tendencialmente benéfico ou maléfico para uma dada realidade, dependendo do que se entenda por desenvolvimento e qual a natureza do turismo em questão, ou seja, de que forma ele é promovido, se baseado em uma lógica predatória ou não, e, finalmente, quais grupos da área de destino se encontram envolvidos. Dessa forma, em meio à identificação de diferentes abordagens de desenvolvimento, cabe indagar, com base nas estratégias propostas, até que ponto elas diferem entre si quanto à forma de inserção e contestação da ordem existente, do ponto de vista social e econômico.

O que se deve questionar, então, é a necessidade de se associar estes princípios a uma tipologia ou denominação específica de turismo, e se esses deveriam ser princípios comuns a todo tipo de turismo que se quer diverso ao seu modelo tradicional. A tipificação do turismo foi compreendida como uma prática que encerra em si mesma a possibilidade de representar, na realidade, uma mudança, a partir do momento em que vincula determinados princípios a um tipo especial de turismo e, dessa forma, propicia sua redução a um mero fator comercial e competitivo frente aos demais segmentos.

Quando se reflete sobre a iniciativa da promoção do turismo a partir de princípios norteadores, aproxima-se mais da possibilidade de incidir no viés 
dominante (econômico) prevalecente da atividade, do que apenas segmentar o turismo em mais um produto a ser absorvido pelo mercado. A construção e a consolidação de um modelo de turismo alternativo em contraposição ao modelo tradicional passam, assim, pela orientação a partir de uma perspectiva de desenvolvimento que possibilita a concretização destes princípios. Porém, o que diferencia tais modelos de turismo de seu correspondente tradicional ou globalizado, conforme se refere Coriolano (2008), são seus princípios e práticas e não somente sua nomenclatura. A partir daí, torna-se notória a ausência do novo no campo dos estudos turísticos, limitando-se tais "alternativas" a meras novidades que se destacam pelo forte caráter efêmero.

Pode-se notar, ainda, que o desenvolvimento na escala do local é apontado como uma via capaz de produzir alguma mudança na ordem estabelecida. Conforme é apresentado pelos autores que defendem e acreditam nesta abordagem de desenvolvimento, torna-se possível construir uma "nova" lógica de promoção do turismo ao propiciar, para a comunidade que se localiza em uma área detentora de potencial turístico, a oportunidade de estar à frente dos rumos que a atividade toma. Com base nessa lógica dada oportunidade às comunidades envolvidas com o turismo de se inserirem no processo enquanto sujeitos ativos de mudança e não somente como receptores passivos de benefícios, muitos deles precários e que pouco contribuem para uma mudança significativa na vida destas pessoas.

É a escala do local, dentro da perspectiva de promoção do turismo e de sua inserção enquanto estratégia de desenvolvimento, a melhor para a consolidação dos modelos alternativos da atividade? É necessário questionar se a abordagem local de desenvolvimento, apropriada pelos estudos turísticos, consiste apenas em uma mera adaptação frente ao modelo econômico predominante ou se ela realmente é uma oposição libertadora frente à ordem econômica predominante e homogeneizante. É importante lembrar que, para alguns autores, como Candiotto (2007), a promoção do turismo em escala local não necessariamente irá implicar em um maior potencial de sustentabilidade, já que todos os lugares e localidades encontram-se inseridos, com maior ou menor intensidade, na dinâmica global do capitalismo, ditada pelo regime de acumulação flexível. De qualquer forma, está posta a questão.

Outro ponto de destaque foi que as abordagens utilitarista/econômica e sustentável - ao apresentarem, predominantemente, características tais como o forte caráter econômico, a utilização do desgastado chavão sustentável como um fator comercial e competitivo, entre outras - tornam-se quase um único enfoque de compreensão do desenvolvimento a partir do turismo. Destaca-se, também, em especial nas abordagens sustentável e comunitária/local, que, ao se apropriar de uma determinada perspectiva de leitura do desenvolvimento, há uma significativa diferença entre o que é o desenvolvimento e o que ele realmente deveria ser.

Importa destacar, ao final, que a identificação de três abordagens não visa encerrar tal discussão, em virtude da sua complexidade e das inúmeras possibilidades de compreensão existentes. Mais do que limitar as maneiras de se compreender o desenvolvimento quando relacionado ao turismo, busca-se apontar quais são as 
abordagens ou os enfoques de desenvolvimento que estão implícitos na literatura e nos autores de turismo em tela nesse artigo. Reitera-se, por outro lado, que o esforço aqui realizado de lançar um olhar sobre o turismo, tendo em vista suas abordagens de desenvolvimento, torna possível sua compreensão e apreensão em uma perspectiva que se posiciona para além das tipologias de turismo. Lembrando, para tanto, que usualmente as tipologias são utilizadas enquanto uma maneira de classificar a atividade, assumindo, diversas vezes, a forma de um rótulo "alternativo" para a promoção do turismo.

\section{Referências bibliográficas}

ABRAMOVAY, R. O capital social dos territórios: repensando o desenvolvimento rural. Seminário sobre Reforma Agrária e desenvolvimento sustentável. Fortaleza, 1998.18p.

ARBIX, G.; ZILBOVICIUS, M. Por uma estratégia de civilização. In: ABRAMOVAY, R.; ARBIX, G.; ZILBOVICIUS, M. (Orgs.). Razões e ficções do desenvolvimento. São Paulo: Unesp/EDUSP; 2001. p. 55-69.

ARMENDARIZ, P.; SERRANO, H. O turismo de base comunitária como uma estratégia para o desenvolvimento: A experiência do Equador. In: SILVA, J.S.; NEUHAUS, E. (Org.). Um Outro Turismo é Possível! Reflexões sobre desigualdades, resistências e alternativas no desenvolvimento turístico. Fortaleza: FBOMS - Fórum Brasileiro de ONGs e Movimentos Sociais para o Meio Ambiente e o Desenvolvimento, 2006. p. 47-52.

BARRETTO, M.; SANTOS, R.J. Fazer científico em turismo no Brasil e seu reflexo nas publicações. Turismo: Visão e Ação. Itajaí, v. 7, n. 2, p. 357-364, 2005.

BENEVIDES, I.P. Para uma agenda de discussão do turismo como fator de desenvolvimento local. In: RODRIGUES, A.B. (Org.). Turismo e Desenvolvimento Local. São Paulo : HUCITEC, 1997. p. 23-41.

BRESSER-PEREIRA, L.C. O conceito histórico de desenvolvimento econômico. São Paulo: FGV-EESP, 2006 (Texto para Discussão n. 157, FGV-EESP, dezembro 2006).

BUTLER, R. Sustainable Tourism: Looking Backwars in order to Progress? In: HALL, M.; LEW, A. (Ed.). Sustainable Tourism: a Geographycal Analysis. Essex, UK: Addison Wesley Longman Limited, 1998. p. 25-34.

CANDIOTTO, L.; ZANETTI, P. Considerações sobre o conceito de turismo sustentável. Formação. Presidente Prudente, v. 1, p. 48-59, 2009.

CARDOSO, F.H. As idéias e seu lugar: ensaios sobre as teorias do desenvolvimento. 2. ed. Petrópolis: Vozes, 1993. 244 p.

CORIOLANO, L.N.M.T. et al. Arranjos Produtivos Locais do Turismo Comunitário: atores e cenários em mudança. Fortaleza: EDUECE, 2008. v. 1. 307. 
CORIOLANO, L.N.M.T. O desenvolvimento voltado às condições humanas e o turismo comunitário. 2003. Disponível em: <http://www.naya.org.ar/turismo/ congreso2003/ ponencias/Luzia Neide Coriolano.htm>. Acesso em: 14 abr. 2010.

CORIOLANO, L.N.M.T. Os limites do desenvolvimento e do turismo. PASOS. Sauzal (Tenerife), v. 1, n. 2, p. 161-171. jun. 2003.

COSTA, H.S.M. Meio ambiente e desenvolvimento: um convite à leitura. In: HISSA, C.E.V. (Org.). Saberes ambientais. Desafios para o conhecimento disciplinar. Belo Horizonte: Editora UFMG, 2008. v. 1, p. 79-107.

ESTEVA, G. Desenvolvimento. In: SACHS, W. Dicionário do desenvolvimento: guia para o conhecimento como poder. Petrópolis: Vozes, 2000. p. 59-83.

FARIA, L.O. Uma reflexão sobre o fortalecimento das instituições, o Desenvolvimento e a Democracia. Anais do Encontro Nacional de Pós Graduação em Administração ENANPAD, 2006, Salvador. Anais do Encontro Nacional de Pós Graduação em Administração, 2006.

GETZ, D. Festivals, Special Events and Tourism. Nova York: Van Nostrand Reinhold, 1991.

GOELDNER, C.R.; RITCHIE, J.R.B.; MCINTOSH, R.W. Turismo: princípios, práticas e filosofias. 8. ed. Porto Alegre: Bookman, 2002.

GOMES, B; M. A.; FERREIRA, J.C.B.; SANTOS, A. C. Uma abordagem crítica da atividade turística. Caderno Virtual de Turismo (UFRJ), Rio de Janeiro: UFRJ, v. 19, p. 40-48, 2006.

HALL, C. M. Planejamento turístico. Políticas, processos e relacionamentos. São Paulo: Contexto, 2001.

IGNARRA, L. R. Fundamentos do turismo. São Paulo: Pioneira, 1999. 135p.

JAFARI, J. La cientifizacion del turismo. Estúdios y perspectivas en turismo, v. 3, n.1, p.735, 1994.

JAFARI,J. Tourism research: revamping old challenges for integrative paradigms. Anais do VII Congreso Nacional y I Internacional de Investigación Turística, Guadalajara, México, 5 de outubro de 2005.

LICKORISH, L.J.; JENKINS, C.L. Introdução ao turismo. Rio de Janeiro: Campus, c2000. $317 \mathrm{p}$.

LOBO, C. Desenvolvimento e qualidade de vida: limitações na utilização de indicadores do crescimento econômico. Cadernos do Leste. Belo Horizonte: IGC/LESTE, v. 1, n. 3, p. 0131. out. 2001.

LOHMANN, G.; PANOSSO NETTO, A. Teoria do Turismo - Conceitos, Modelos e Sistemas. São Paulo: Editora Aleph, 2008 (Série Turismo). 468p.

LUCHIARI, M.T.D.P. Urbanização turística: um novo nexo entre o lugar e o mundo. In: LIMA, L.C. (Org.). Da cidade ao campo: a diversidade do saber-fazer turístico. Fortaleza: Ed. UECE, 1998. p. 15-29. 
Malta, G.A.P.; Barbosa, M.F.P.

MAGALHÃES, L.H. Discussão crítica acerca do turismo numa perspectiva materialista histórica. Caderno Virtual de Turismo (UFRJ), v. 8, p. 95-104, 2008.

MOESCH, M.M. A produção do saber turístico. São Paulo: Contexto, 2001.

O`CONNOR, J. Capitalism, Nature, Socialism: Theoretical Introduction. Capitalism, Nature, Socialism. London, v. 1, n. 1, p. 11-38,1988.

OLIVEIRA, F.M.; COSTA, G.M.; Espaço, lugar, identidade e urbanização conceitos geográficos na abordagem do Turismo. Dissertação (Mestrado em Geografia) - Instituto de Geociências, Universidade Federal de Minas Gerais, Belo Horizonte. 2006. $125 f$.

ORGANIZAÇÃO MUNDIAL DO TURISMO (OMT). Introdução ao Turismo. Trad. Dolores M. R. Corner. São Paulo: Roca, 2001.

OURIQUES, H.R. Elementos para uma crítica do turismo na economia-mundo capitalista. Anais do II COLÓQUIO BRASILEIRO EM ECONOMIA POLÍTICA DOS SISTEMASMUNDO, 2008, Florianópolis. Anais..., Florianópolis, 2008.

QUEIROZ, L.M.A. A gestão pública e a competitividade de cidades turísticas: a experiência da cidade do Salvador. 2005. 631f. Tese (Doutorado em Planificação Territorial e Desenvolvimento Regional). Universidade de Barcelona. Barcelona, 2005.

QUINTERO, M.S. Estratégias de resistência frente aos impactos do turismo em Esmeraldas, Equador. In: SILVA, J.S.; NEUHAUS, E. (Org.). Um Outro Turismo é Possível! Reflexões sobre desigualdades, resistências e alternativas no desenvolvimento turístico. Fortaleza: FBOMS - Fórum Brasileiro de ONGs e Movimentos Sociais para o Meio Ambiente e o Desenvolvimento, 2006. p. 63-65.

REIS, M. C. Apreensão da realidade, projetos políticos em disputa e desenvolvimento: Notas a partir das contribuições de Fernand Braudel, Norbert Elias e Boaventura de Sousa Santos. Anais do XII Congresso Brasileiro de Sociologia, 2005. Belo Horizonte. Anais do XII Congresso Brasileiro de Sociologia, 2005.

RIBEIRO, G. L. Poder, redes e ideologia no campo do desenvolvimento. Novos Estudos. CEBRAP, v. 80, p. 109-125, 2008.

RODRIGUES, A. B. Turismo local: oportunidades para inserção. In: RODRIGUES, A.B. (Org.). Turismo e Desenvolvimento Local. São Paulo: HUCITEC, 1997. p. 55-64.

SANTOS, B.S. Produzir para viver. 2. ed. Rio de Janeiro: Civilização Brasileira, 2005.

SANTOS, B.S. Renovar a teoria crítica e reinventar a emancipação social. São Paulo: Boitempo Editorial, 2007.

SANTOS, M.M.C.; MARINHO, M.F.; POSSAMAI, A.M.P. Pesquisa em Turismo: Panorama das Teses de Doutorado produzidas no Brasil de 2005 a 2007. Revista brasileira de pesquisa em turismo, v. 3, p. 3-33, 2009.

SEN, A. Desenvolvimento como Liberdade. São Paulo: Companhia das Letras, 2000. $409 \mathrm{p}$.

SINGER, P. 1982. Desenvolvimento e Crise. Rio de Janeiro: Paz e Terra

Página 892 Revista Brasileira de Ecoturismo, São Paulo, v.6, n.5, nov 2013-jan 2014, pp.862-895. 
SOLHA, K.T.; TULIK, O. Órgãos públicos estaduais e o desenvolvimento do turismo no Brasil. 2004.178f. Tese (Doutorado em Relações Públicas, Propaganda e Turismo). Escola de Comunicações e Artes da Universidade de São Paulo. São Paulo, 2004.

SOUZA, M.J.L. Como pode o turismo contribuir para o desenvolvimento local? In: RODRIGUES, A.B. (Org.). Turismo e Desenvolvimento Local. São Paulo: HUCITEC, 1997. p. 17-22.

SOUZA, M.L.A teorização sobre o desenvolvimento em uma época de fadiga teórica, ou: sobre a necessidade de uma "teoria aberta" do desenvolvimento sócio-espacial. TERRITÓRIO. Rio de Janeiro, LAGET/UFRJ, v. 1, n. 1, p. 5-19. dez. 1996.

SOUZA, N.J. Desenvolvimento econômico. São Paulo: 1993. 242p.

WALL, G. Planning. In: JAFARI, J. Encyclopedia of Tourism. Londres: Routledge, 2000. p. 439-440.

\section{Notas:}

${ }^{1} \mathrm{O}$ presente trabalho deriva-se da temática discutida na dissertação de mestrado intitulada Turismo e Desenvolvimento: análise de uma complexa relação considerando as abordagens e concepções presentes na literatura do turismo, defendida em março de 2011 na Universidade Federal de Minas Gerais (UFMG), Belo Horizonte.

${ }^{2}$ Ao se falar em desenvolvimento são feitas referências, sobretudo, às três principais dimensões que estão circunscritas em seu bojo - melhora, ação e processo - que, no contexto dos debates em torno desse tema, encontram-se inextricavelmente relacionadas.

${ }^{3}$ Para se ter uma noção desta amplitude de enfoques, segundo Lohmann e Netto (2008) há cerca de 150 modelos de abordagens do turismo.

${ }^{4}$ Este trabalho se vale do argumento apresentado por Marcelo Lopes de Souza (1996), no qual afirma ser preferível o uso da palavra 'ideia' ao termo 'conceito' quando se pretende referir ao tema do desenvolvimento (de forma geral), como aqui abordado. Isso se justifica, segundo Souza (1996), pelo fato de que o uso indiscriminado do termo conceito, enquanto palavra que precede e qualifica o desenvolvimento, pode dar a impressão de haver ou ser possível um conceito unívoco de desenvolvimento.

${ }^{5} \mathrm{Na}$ tentativa de identificar e organizar as diversas áreas que se inter-relacionam com o turismo, vários autores buscaram por meio de modelos representar o seu caráter multidisciplinar. Ver em especial os modelos de: Jafar Jafari (1981) e John Tribe (1997).

${ }^{6} \mathrm{O}$ termo "turismologia", surgido na década de 1960 se refere à ciência centralizada no estudo do turismo. Apesar de pouco utilizada pela literatura especializada da área, esta abordagem visa conhecer e estudar o turismo em sua totalidade.

${ }^{7}$ Originalmente Jafar Jafari publicou o primeiro estudo a respeito das fases de estudo pelas quais o turismo passou em 1994, sendo atualizado em 2005. Para maiores detalhes ver: JAFARI, J. Tourism research : revamping old challenges for integrative paradigms. Anais do VII Congreso Nacional y I Internacional de Investigación Turística, Guadalajara, México, 5 de outubro de 2005.

Página 893 Revista Brasileira de Ecoturismo, São Paulo, v.6, n.5, nov 2013-jan 2014, pp.862-895. 
${ }^{8} \mathrm{O}$ discurso associado a esta plataforma e que se refere, predominantemente, aos aspectos positivos do turismo, ainda hoje se faz presente, sobretudo, associado a projetos políticos que se apropriam do turismo como proposta de governo e estratégia de desenvolvimento.

${ }^{9}$ Estas opções de turismo são a priori identificadas como menos agressivas e nocivas ao ambiente no qual ocorrem em oposição ao turismo de massa, identificado como extremamente prejudicial ao meio ambiente, responsável por diversos danos ambientais e sociais.

${ }^{10}$ Goeldner et al (2002, p. 28) apresenta oito abordagens básicas de estudo do turismo:

1. Abordagem institucional; 2.Abordagem de produto; 3.Abordagem histórica; 4.Abordagem gerencial; 5.Abordagem econômica; 6.Abordagem sociológica; 7.Abordagem geográfica; 8.Abordagens interdisciplinares.

11 Na visão de Souza (1997) o termo desenvolvimento carrega em si uma carga ideológica conservadora (etnocêntrica e capitalistófila) no qual se encontra enraizada no solo cultural denominado modernidade, proveniente da entidade histórico-geográfica chamada Ocidente. Para o autor, é de fundamental importância notar que a maneira atual de se compreender o termo desenvolvimento, enquanto valor social almejado por diferentes nações, se encontra flagrantemente influenciado pelo projeto capitalista e pelo processo de conquista e colonização que fora capitaneado pela Europa.

${ }^{12} \mathrm{Na}$ análise de Cardoso (1993) sobre a construção de um outro desenvolvimento, são apresentadas algumas pistas do que um novo modelo de desenvolvimento deverá priorizar. Ao qualificá-lo como um estilo mais igualitário de desenvolvimento, Cardoso cita o conceito de "ecodesenvolvimento", trabalhado por Ignacy Sachs, como aquele que defende um crescimento autônomo e diferenciado, respeitador das características culturais, espaciais e políticas do Terceiro Mundo.

13 Segundo Cardoso (1993), a proposição de um outro desenvolvimento passava pela construção de uma nova utopia, que se baseava na refutação da exploração do homem pelo homem e, por isso, mostrava-se mais inclusiva e menos racionalista que a utopia do século XIX, que a antecedeu. O objetivo principal, portanto, desse outro desenvolvimento, de acordo com o autor, era um bem-estar coletivo e não um aumento da produção.

${ }^{14}$ Segundo Boaventura de Sousa Santos (2002, p.56) o que designamos por globalização "[...] é de fato uma constelação de diferentes processos de globalização e, em última instância, de diferentes e, por vezes, contraditórias globalizações". Nesse sentido, não existe na visão do autor uma entidade única chamada globalização, existem, ao contrário, globalizações.

15 A respeito da diferença entre propostas de desenvolvimento alternativo e de alternativas ao desenvolvimento, ver Boaventura de Sousa Santos (2005, p.25-55).

${ }^{16}$ A "ecologia dos saberes", como trabalhado por Boaventura de Sousa Santos, refere-se à promoção de diálogos entre o saber científico ou humanístico que a universidade produz e os saberes leigos, populares, tradicionais, urbanos, camponeses provenientes de culturas não ocidentais que circulam na sociedade. A ecologia dos saberes vem,

Página 894 Revista Brasileira de Ecoturismo, São Paulo, v.6, n.5, nov 20I3-jan 20I4, pp.862-895. 
dessa forma, a ser um dos conceitos fundamentais para a proposta da epistemologia do Sul. Em suma, ela se refere à produção de um diálogo horizontal, entre saberes.

${ }^{17}$ Refere-se aqui à autonomia conforme trabalhada por Marcelo Lopes de Souza (1999), que a define não como uma utopia idealista, a exigir como premissa uma sociedade uniforme e sem conflitos, mas, simplesmente, como um horizonte de pensamento e ação, a estimular um caminhar marcado por dissensões que, sobre a base do agir comunicativo e com o concurso de uma razão critica, não precisarão ter como corolário a violência.

${ }^{18}$ Ver: Reis (2005).

${ }^{19}$ BRASIL, MINISTÉRIO DO TURISMO. Plano Nacional de Turismo 2007/2010. Uma viagem de inclusão. Brasília: MTur, 2007.

${ }^{20} \mathrm{http}: / /$ www.capacitacaoemturismo.org.br

Guilherme Augusto Pereira Malta: Universidade Federal de Minas Gerais, Belo Horizonte, MG, Brasil.

Email: guilherme.malta@gmail.com

Link para o currículo Lattes: http://lattes.cnpq.br/7723375211499046

Maria Flávia Pires Barbosa: Universidade Federal de Minas Gerais, Belo Horizonte, MG, Brasil.

Email: pires_flavia@yahoo.com.br

Link para o currículo Lattes: http://lattes.cnpq.br/3469566283414298

Data de submissão: 06 de junho de 2012

Data de recebimento de correções: 01 de agosto de 2013

Data do aceite: 27 de agosto de 2013

Avaliado anonimamente 